\title{
LSIL/ASC-H (LSIL-H) in Cervicovaginal Smear: Histopathological Outcomes and Clinical Significance
}

\author{
Servikovajinal Yayma'da LSIL/ASC-H (LSIL-H): \\ Histopatolojik Sonuçlar ve Klinik Önem
}

\author{
Ecmel IŞIK KAYGUSUZ, Handan ÇETINER, Davut ŞAHIN
}

Department of Pathology, Zeynep Kamil Hospital, ISTANBUL, TURKEY

\begin{abstract}
Objective: Conventional Pap smears exhibiting unequivocal features of 'low grade squamous intraepithelial lesion' (LSIL) are occasionally mixed with some cells suspicious for, but not diagnostic of 'high grade squamous intraepithelial lesion' (HSIL) on daily routine. The 2001 Bethesda System does not address the significance of such cytological entities. We have referred to these changes in our laboratory as 'LSIL, atypical squamous cells cannot exclude HSIL' (LSIL/ASC-H). In this study, we aimed to compare the cytology and biopsy results of LSIL/ ASC-H to LSIL, ASC-H and HSIL.
\end{abstract}

Material and Method: Out of 37884 cases which were evaluated between 2005-2009 in our laboratory, cases interpreted as LSIL, LSIL/ ASC-H, HSIL and ASC-H were reevaluated and 153 cases for which biopsy materials were available were selected.

Results: The rate of histological CIN2 or worse associated with LSIL/ ASC-H (45\%) was between the rates of LSIL (10\%) and HSIL (65\%), but not significantly different from ASC-H (50\%). However, LSIL/ ASC-H was more frequently associated with a definitive histological diagnosis of any CIN2 than ASC-H (30\% vs. 8\%).

Conclusion: Based on our results, we recommend LSIL/ASC-H to be added to Bethesda System, and Pap test cases of LSIL/ASC-H may need to be clinically followed-up in a manner similar to ASC-H, i.e., with colposcopy for all patients.

Key Words: Vaginal smears, Cervical intraepithelial neoplasia
ÖZ

Amaç: Günlük uygulamada, 'low grade squamous intraepithelial lesion' (LSIL) bulgulari ile birlikte 'high grade squamous intraepithelial lesion' (HSIL) için tanısal olmamakla beraber kuşkulu hücreler içeren konvansiyonel Pap yaymalar olabilmektedir. Bethesda 2001 sistemi bu antiteye yer vermemiştir. Laboratuvarımızda bu tür değişiklikler gösteren konvansiyonel Pap yaymalara 'HSIL dışlanamayan atipik skuamöz hücreler içeren LSIL (LSIL/ASC-H) tanısı vermekteyiz. Çalışmamızda; LSIL/ASC-H ile LSIL, HSIL ve ASC-H' li olguların sitoloji ve biyopsi sonuçlarını karşılaştırmayı hedefledik.

Gereç ve Yöntem: Laboratuvarımızda 2005-2009 yılları arasında değerlendirilmiş 37884 olgu içerisinden LSIL, LSIL/ASC-H, HSIL ve ASC-H olarak tanı almış olgular yeniden değerlendirildi ve biyopsi materyalleri bulunan 153 olgu seçildi.

Bulgular: LSIL/ASC-H ile ilişkili histolojik olarak CIN2 ve üzeri bir lezyon bulunma oranı (\%45), LSIL (\%10) ve HSIL (\%65) arasında bir değer iken ASC-H (\%50)'den anlamlı olarak farklı değildi. Bununla birlikte, ASC-H’ye göre LSIL/ASC-H (\%8 e karşllı \%30) daha sıklıkla, CIN2 tanısı ile ilişkili idi.

Sonuç: Çalışma sonuçlarımıza bağlı olarak; LSIL/ASC-H'nin Bethesda sistemi'ne eklenmesini ve Pap test sonuçları LSIL/ASC-H olan olguların klinik olarak ASC-H gibi izlenmesini (bütün olgulara kolposkopi yapılması, vb.) önermekteyiz.

Anahtar Sözcükler: Vajinal yaymalar, Servikal intraepiteliyal neoplazi

\section{INTRODUCTION}

Early cytological diagnosis and treatment of high-grade squamous intraepithelial lesions (HSIL) play a critical role in protection from cervical cancer. Smears with cells that are suspicious though not diagnostic for HSIL and no squamous intraepithelial lesion in the background were included in the Bethesda System in 2001 as 'atypical

Received : 30.06 .2010

Accepted : 24.10 .2010 squamous cells where HSIL cannot be excluded' (ASH-C) as it has been shown to be effective in the histopathological determination of HSIL cases during follow-up (1). However, some smears encountered during the daily routine contain cells that are not diagnostic but suspicious regarding HSIL in addition to marked low-grade squamous intraepithelial lesion (LSIL) findings in the background. These cases are

Correspondence: Ecmel IŞIK KAYGUSUZ

Department of Pathology, Zeynep Kamil Hospital, İSTANBUL, TURKEY

E-mail: ecmeli@yahoo.com Phone: +90 2163910680 
frequently reported as LSIL/ACH or LSIL where HSIL cannot be excluded (LSIL-H). Recent studies have found the rate of a cervical intraepithelial lesion 2 (CIN2) or higher diagnosis in these biopsy materials to be higher than those that received a diagnosis of LSIL only (2-9). This rate is seen to be similar to that of receiving a diagnosis of CIN2 or above on histopathology for patients with a diagnosis of ASC-H. We aimed to compare the LSIL/ASC-H diagnosis and LSIL-ASC-H, HSIL diagnosis in conventional Pap smears and to evaluate the clinical significance of these results especially for LSIL/ASC-H in this study.

\section{MATERIAL and METHOD}

The smears that had received a diagnosis of ASC-US, LSIL, ASC-H, LSIL/ASC-H, or HSIL among the 37884 conventional Pap smears screened at our hospital between January 2005 and December 2009 were re-evaluated and a total of 153 patients who had undergone a biopsy within one year after the Pap smear were included in the study. The dysplasia with the highest degree was recorded from the biopsy results in cases that had undergone multiple biopsies. The results were classified under 5 histopathological diagnoses as benign, CIN1, CIN2, CIN3 and cancer.

A LSIL/ASC-H diagnosis was made in smears with ASC$\mathrm{H}$ changes among an LSIL appearance (Figure 1). The following cytomorphological results were used in defining ASC-H cells, based on previously reported studies (9-11); (1) the presence of usually 5 or less dysplastic cells with HSIL-like findings, (2) the presence of atypical metaplastic squamous cells, (3) the presence of cells with an N/C ratio between LSIL and HSIL (Figure 2).

The biopsy result distribution between the groups was analyzed by using only SIL cases (a total of 153) to calculate the positive predictive value (PPV).

\section{RESULTS}

We found that 37884 conventional Pap smears screened between 2005 and 2009 had been reported as follows: 'Atypical squamous cells of unknown importance' (ASCUS) $1.2 \%$ (461 cases), LSIL $0.15 \%$ (57 cases), ASC-H 0.06\% (25 cases), LSIL/ASC-H 0.10\% (40 cases), HSIL 0.08\% (31 cases), HSIL+ invasive carcinoma not excluded $0.02 \%$ (10 cases), atypical glandular cells (AGC) $0.02 \%$ (10 cases), squamous cell carcinoma (SCC) $0.05 \%$ (19 cases), and adenocarcinoma $0.01 \%$ ( 4 cases) (Table I).

The total rate of atypical cytology as diagnosed by a conventional Pap smear was 1.69\% (657 cases).

The percentages of preinvasive cervical neoplasms and invasive neoplasms were $1.63 \%$ and $0.06 \%$, respectively.

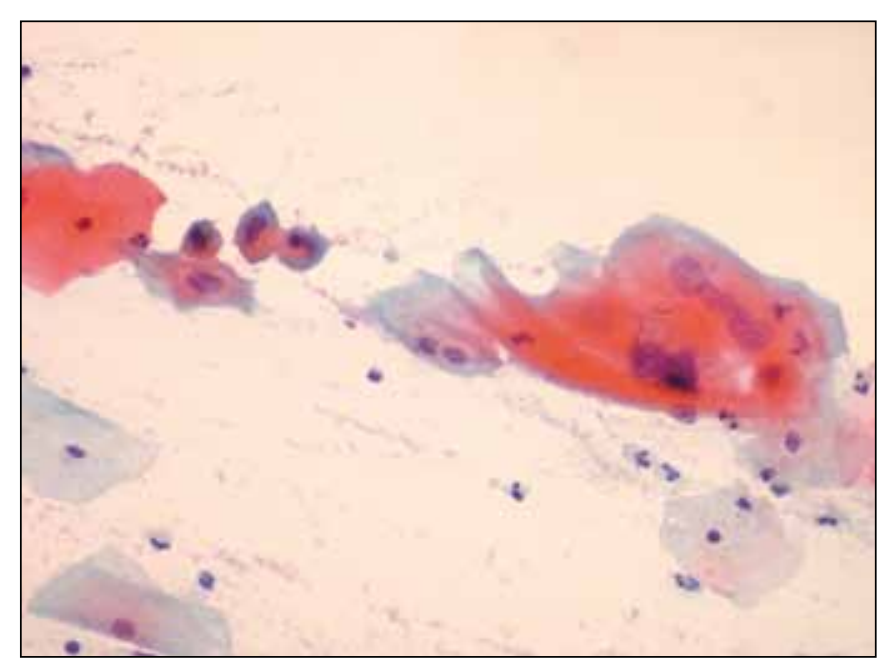

Figure 1: LSIL/ASC-H (Pap; x200).

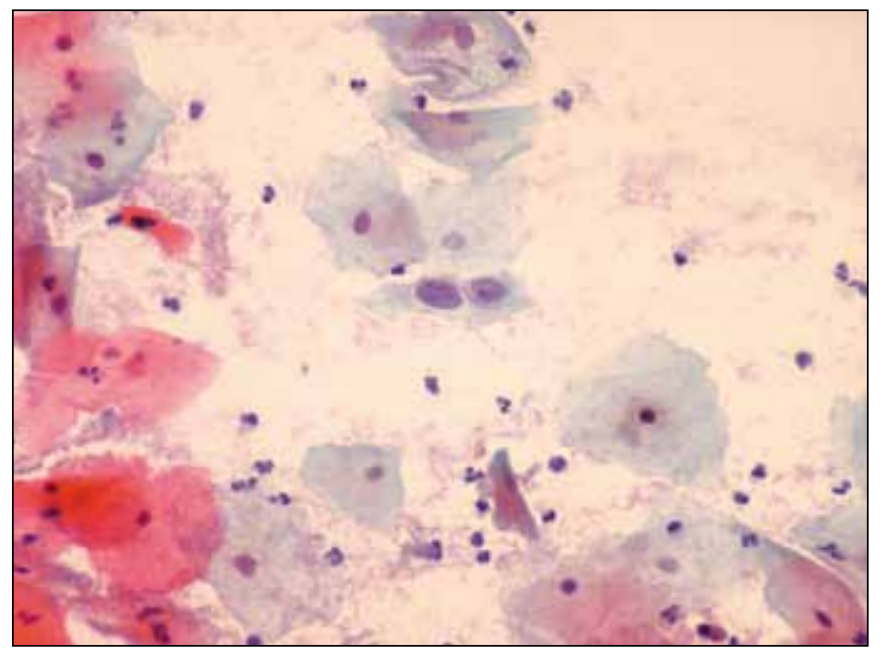

Figure 2: ASC-H (Pap; x200).

There were a total of 371 (56\%) cases that had received a diagnosis of atypical cytology by Pap smear with a histopathological lesion on biopsy. These cases were distributed as CIN 1 in 47\% (175 cases), CIN 2 in 28\% (103 cases), CIN 3 in 19\% (80 cases) and invasive cancer in 6\% (23 cases) (Table II).

We found that the percentage of cases which underwent a biopsy within a year after Pap smear was $17.5 \%$ (10 cases) for LSIL, $48 \%$ (12) for ASC-H, 50\% (20 cases) for LSIL/ ASC-H and 74\% (23 cases) for HSIL.

1. A CIN2 or higher lesion had been found in $45 \%$ of LSIL/ ASC-H cases (PPV=45\%). This rate was higher than for LSIL cases $(10 \%, \mathrm{PPV}=10 \%)$, similar to ASC-H cases $(50 \%, \mathrm{PPV}=50 \%)$ and lower than for HSIL cases $(65 \%$, PPV $=65 \%$ ) (Table III). 
2. Classifying high-grade intraepithelial neoplasms as moderate (CIN2) or severe (CIN3) and higher, we found a CIN3 or higher lesion in 15\% of biopsies from LSIL/ ASC-H cases. This rate was similar to LSIL cases (10\%) and lower than in ASC-H (42\%) and HSIL (52\%) cases.

3. The rate of CIN2 in the biopsies was $30 \%$ in the LSIL/ ASC-H group. This rate was higher than in LSIL (0\%), ASC-H (8\%) and HSIL (13\%).

4. The rate of CIN1 in the biopsies was $35 \%$ for LSIL/ASCH cases. This rate was higher than in the LSIL group (70\%), similar to the ASC-H group (33\%) and higher than in the HSIL group (10\%).

5. We found no significant difference between the benign diagnosis rates in cases with an LSIL/ASC-H diagnosis (20\%) and the other groups (LSIL 20\%, ASC-H 17\%, HSIL 26\%).

Our results showed that CIN2 rate was higher in the biopsies of the LSIL/ASC-H group compared to the ASC-H and HSIL groups; CIN3 rate was lower than the ASC-H and HSIL groups, and CIN2 or higher lesion rate was similar to the ASC-H group but lower than the HSIL group. The rate of CIN1 was lower than in the LSIL group.

\section{DISCUSSION}

The conventional PAP smear used today aims to diagnose and treat high-grade cervical diseases including precancerous CIN2, CIN3 and higher. The Bethesda 2001 System separates squamous intraepithelial lesions into 2 groups as low (LSIL) and high (HSIL) squamous intraepithelial lesions (5). This classification is related to the natural course of HPV infection. LSIL has a high chance of regression while the HSIL background contains significant lesions such as CIN2 and CIN3 with a tendency to progress towards malignancy.

Some smears show findings similar to LSIL and HSIL but do not meet all criteria for the diagnosis. The Bethesda 2001 system recommends the two diagnostic categories of ASCUS and ASC-H for such cases. However, there are cases that are difficult to classify as LSIL or HSIL as well. For example, some cases have marked LSIL findings while a few cells have HSIL-like features $(3,5-7)$. There is no diagnostic category in the abbreviated version of Bethesda 2001 for such cases but the Bethesda 2001 manual mentions that such cases can be evaluated as 'indeterminate grade' (1). Laboratories, including our own, define these lesions as LSIL/ASC-H or LSIL-H as they contain both LSIL and ASC-H features.

Table I: Distribution of cervical atypical cytologies [n (\%)]

\begin{tabular}{|c|c|c|c|c|c|c|c|c|}
\hline ASCUS & LSIL & ASC-H & $\begin{array}{c}\text { LSIL/ } \\
\text { ASC-H }\end{array}$ & HSIL & $\begin{array}{c}\text { HSIL+ invasion } \\
\text { cannot be excluded }\end{array}$ & AGC & SCC & Adenocarcinoma \\
\hline 461 & 57 & 25 & 40 & 31 & 10 & 10 & 19 & 4 \\
$(1.2)$ & $(0.15)$ & $(0.06)$ & $(0.10)$ & $(0.08)$ & $(0.02)$ & $(0.02)$ & $(0.05)$ & $(0.01)$ \\
\hline
\end{tabular}

Table II: Histopathological correlation following atypical cytology

\begin{tabular}{|c|c|c|c|c|}
\hline Biopsy diagnosis following atypical cytology & CIN 1 & CIN 2 & CIN 3 & Carcinoma \\
\hline $\mathrm{n}=371(\%)$ & $175(47)$ & $103(28)$ & $70(19)$ & $23(6)$ \\
\hline
\end{tabular}

Table III: Histopathological distribution of LSIL, ASC-H, LSIL/ASC-H, and HSIL diagnoses

\begin{tabular}{|l|c|c|c|c|}
\hline & $\begin{array}{c}\text { LSIL } \\
\mathrm{n}=10(\%)\end{array}$ & $\begin{array}{c}\text { ASC-H } \\
\mathrm{n}=12(\%)\end{array}$ & $\begin{array}{c}\text { LSIL/ASC-H } \\
\mathrm{n}=20(\%)\end{array}$ & $\begin{array}{c}\text { HSIL } \\
\mathrm{n}=23(\%)\end{array}$ \\
\hline Benign & $2(20)$ & $2(17)$ & $4(20)$ & $6(26)$ \\
\hline CIN1 & $7(70)$ & $4(33)$ & $7(35)$ & $2(9)$ \\
\hline CIN2 & 0 & $1(8)$ & $6(30)$ & $3(13)$ \\
\hline CIN3 & $1(10)$ & $5(42)$ & $1(5)$ & $5(22)$ \\
\hline Carcinoma & 0 & 0 & $2(10)$ & $7(30)$ \\
\hline
\end{tabular}


We compared the ASCUS, LSIL, ASC-H, LSIL/ASC-H, and HSIL diagnosis rates according to conventional Pap smear results and the percentage of finding a lesion in the biopsy results of patients with a diagnosis of LSIL, ASC-H, LSIL/ ASC-H, and HSIL in their smear results, as compared to the literature.

Our total cytological abnormality rate was $1.69 \%$ and this was similar to another study from Turkey on the prevalence of cervical cytological abnormalities (1.8\%) (12).

Our LSIL/ASC-H ratio $(0.10 \%)$ was close to that of other authors $(0.15-0.53 \%)(3,5,6)$.

The rate of diagnosing a CIN2 or higher grade lesion on biopsy following an LSIL/ASC-H diagnosis (45\%) was similar to ASC-H (50\%), higher than for LSIL (10\%) and lower than for HSIL (65\%). These results were consistent with recent publications. The potential of LSIL/ASC-H to catch a CIN2 or higher lesion (45\%) was especially consistent with some previous studies $(3,6,16,17)$. The rate of finding a CIN2 or higher lesion in LSIL/ASC-H biopsies was slightly higher than ASC-H in some studies (4,6,7-18) and slightly lower in others $(2,3,5,19)$.

We found a $15 \%$ rate for LSIL/ASC-H to define a CIN3 or higher lesion in biopsy results, similar to Difurio et al. (2) and Alsharif et al. (8) (Difurio et al. 14\%, Alsharif et al. $11 \%)$. This rate was markedly lower than with ASC-H (42\%) and HSIL (52\%).

The CIN2 detection rate of patients with an LSIL/ ASC-H diagnosis was $30 \%$ on follow-up. This rate was higher than with LSIL (0\%), ASC-H (8\%) and HSIL (13\%). Hang et al. (18) and Alsharif et al (8). have also reported that biopsies of patients diagnosed with LSIL/ASC-H have a higher rate of CIN2 diagnosis when found to have a CIN2 or higher lesion and LSIL/ASC-H probably indicates CIN2 as also reported by these authors.

The rate of receiving a diagnosis of CIN1 was $30 \%$ in the LSIL/ASC-H group, $70 \%$ for LSIL, 33\% for ASC-H and $10 \%$ for HSIL. We found the rate of determining the CIN1 diagnosis for the LSIL/ASC-H group to be markedly lower than LSIL. Our results were consistent with previous studies (33.73\%).

We obtained similar values between ASC-H, and LSIL and HSIL as regards determining CIN2 or higher lesions of LSIL-ASC-H. Past studies have reported similar results $(2,8,16)$.

Bethesda 2001 contains two definite squamous intraepithelial lesions (LSIL and HSIL) and two indeterminate squamous intraepithelial lesions (ASCUS and ASC-H). The definite cytological findings of LSIL and HSIL have been defined but there is no separate category for cases that are between LSIL and HSIL and especially those that contain HSIL-like cells that are not diagnostic for HSIL in addition to marked LSIL findings.

Some cases meet the criteria for both LSIL and ASC-H. Such intermediate cases are reported as LSIL, ASC-H or LSIL/ASC-H (LSIL-H). However, these definitions lead to confusion in practice for the clinicians. The rate of patients with a LSIL/ASC-H diagnosis varies greatly in the literature (30\%-72\%). The reason is the inability of the clinician to fully understand these definitions. This rate was $50 \%$ in our study. Colposcopy is advised for all cases that receive a diagnosis of ASC-H according to Bethesda 2001 as they are associated with HSIL. There is no defined clinical approach for LSIL/ASC-H and clinicians act according to their own interpretation. They adopt an approach similar to LSIL especially for postmenopausal or adolescent cases. However, the rate of detecting CIN2 is significantly higher in LSIL/ASC-H than with LSIL, ASC-H, HSIL and it therefore needs to be evaluated separately from LSIL and these patients need to be approached as in ASC-H considering it can possibly indicate a high-grade squamous intraepithelial neoplasm.

In conclusion, we believe that LSIL/ASC-H should be classified as a separate category as there is a high chance of defining the underlying CIN2 and that it should therefore be evaluated separately from LSIL. We found that LSIL/ ASC-H had a high risk of a CIN2 or higher neoplasia like ASC-H but that it had low risk for CIN3 in contrast. The clinical management of CIN2 and CIN3 is similar and the clinical approach to LSIL/ASC-H should be undertaken keeping in mind that it can act like ASC-H.

\section{ACKNOWLEDGEMENTS}

We would like to thank Sadiye Toraman and Selma Porsuk for helping us during this study.

\section{REFERENCES}

1. Solomon D, Davey D, Kurman R, Moriarty A, O'Connor D, Prey M, Raab S, Sherman M, Wilbur D, Wright T Jr, Young N: The 2001 Bethesda System: terminology for reporting results of cervical cytology. JAMA 2002, 287:2114-2119

2. Difurio MJ, Mailhiot T, Sundborg MJ, Nauschuetz KK: Comparison of the clinical significance of the Papanicolaou test interpretations LSIL cannot rule out HSIL and ASC-H. Diagn Cytopathol 2010, 38:313-317

3. Power P, Gregoire J, Duggan M, Nation J: Low-grade pap smears containing occasional high-grade cells as a predictor of highgrade dysplasia. J Obstet Gynaecol Canada 2006, 28:884-887 
4. Howard MT, Cohen DW, Underwood DL, Deeds DA, Booth CN:Utilization of ASC-H, LSIL, cannot exclude HSIL (LSIL-H) and HSIL terminology following implementation of the ThinPrep imaging system. Mod Pathol 2007, 20(Suppl 2):71A

5. Elsheikh TM, Kirkpatrick JL, Wu HH: The significance of "lowgrade squamous intraepithelial lesion, cannot exclude highgrade squamous intraepithelial lesion" as a distinct squamous abnormality category in Papanicolaou tests. Cancer 2006, 108:277-281

6. Owens CL, Moats DR, Burroughs FH, Gustafson KS: "Lowgrade squamous intraepithelial lesion, cannot exclude high-grade squamous intraepithelial lesion" is a distinct cytologic category: histologic outcomes and HPV prevalence. Am J Clin Pathol 2007,128:398-403

7. Shidham VB, Kumar N, Narayan R, Brotzman GL: Should LSIL with ASC-H (LSIL-H) in cervical smears be an independent category? A study on SurePath specimens with review of literature. CytoJournal 2007,4:7

8. Alsharif M, Kjeldahl K, Curran C, Miller S, Gulbahce HE, Pambuccian SE: Clinical significance of the diagnosis of lowgrade squamous intraepithelial lesion, cannot exclude high-grade squamous intraepithelial lesion. Cancer Cytopathol 2009,117: 92-100

9. Kir G, Cetiner H, Gurbuz A, Karateke A: Reporting of "LSIL with ASC-H" on cervicovaginal smears: is it a valid category to predict cases with HSIL follow-up? Eur J Gynecol Oncol 2004, 25 : 462-464

10. Chivukula M, Shidham VB: ASC-H in Pap test--definitive categorization of cytomorphological spectrum. Cytojournal 2006, $3: 14$

11. Hunter C, Duggan MA, Duan Q, Power P, Gregoire J, Nation J: Cytology and outcome of LSIL: cannot exclude HSIL compared to ASC-H. Cytopathology 2009, 20:17-26
12. Turkish Cervical Cancer and Cervical Cytology Research Group: Prevalence of cervical cytological abnormalities in Turkey. Int J Gynaecol Obstet 2009, 106:206-209

13. Solomon D, Nayar R: The Bethesda System for Reporting Cervical Cytology: Definitions, Criteria, and Explanatory Notes. 2nd ed. New York, Springer, 2004, 38-52

14. McGrath CM, Kurtis JD, Yu GH: Evaluation of mild-to-moderate dysplasia on cervical-endocervical (Pap) smear: a subgroup of patients who bridge LSIL and HSIL. Diagn Cytopathol 2000, 23:245-248

15. Deeds D, Underwood DL, Booth CN: Comparison of Pap test fiveyear retrospective reviews for high grade squamous intraepithelial lesion (HSIL) and low grade squamous intraepithelial lesion, cannot exclude HSIL (LSIL-H). Cancer (Cancer Cytopathol) 2007, 111 (suppl 5): 447-448

16. Booth C, Massarani-Wafai R, Salhadar A, Weirick J, Wojcik EM: Is LSIL, cannot exclude HSIL (LGHSIL) a valid Pap test interpretation. Mod Pathol 2005,18:61A

17. Jain R, Paedigo MA,Powers CN, Frable WJ: Significance of reporting 'LSIL-H' on cervical cytologic specimens. Cancer Cytopathol 2005, 105:355-356

18. Hong SR, Kim BM, Park JS, Choi KJ, Kim HS, Kim HS: Evaluation of low-grade squamous intraepithelial lesion, cannot exclude high-grade squamous intraepithelial lesion on cervical smear. Cancer (Cancer Cytopathol) 2006, 108 (suppl 5): 387

19. Underwood D, Prok A, Booth C, Brainard J, Chen L: Clinical outcomes of patients with a cytologic interpretation of 'LSIL, cannot exclude HSIL (LSIL-H)' in Pap tests: a retrospective follow-up study. Cancer Cytopathol 2006, 108: 378 